\title{
Meridel Le Sueur: Toward a New Regionalism
}

\author{
NEALA J.Y. S CHLE U N ING
}

Meridel Le Sueur was born February 22, 1900, in Murray, Iowa. In a recent film produced on her life and writings, she summed up her feelings for the Midwest: "I was born on the prairie, in the middle of winter, in a square puritan house at the beginning of a most brutal century-the twentieth century. I was born out of the body of woman, earth, village, and the American people." 1 The small white house stands disconsolately in Murray to this day, neglected and aging, its peeling paint and overgrown vegetation a silent tribute to the passage of the years and the impermanence of structures. Le Sueur's works, however, and the culture of the Midwest that inspired her, proved more durable. Seldom has the prairie been infused with deeper sensitivity and greater passion than through the eyes and heart of this poet-feminist-philosopher.

\section{I}

Le Sueur was born into a family destined to leave a strong mark on midwestern politics and culture. Their lifelong commitment to political activism would serve to counterpoint Le Sueur's passion for writing, and throughout her life she has struggled to integrate art and politics. Both her mother, Marion, an admirer of Emerson, and her stepfather, Arthur Le Sueur, were influential in her development as a native American radical. Arthur was a lawyer and the first Socialist mayor of Minot, North Dakota, where he was active in the Nonpartisan League. ${ }^{2} \mathrm{He}$ and Marion met at the Workers College in Fort Scott, Kansas, which had been established prior to the First World War by Charles Steinmetz and Eugene V. Debs. Early mem-

1 Femme Films, Inc., My People Are My Home. 16mm, 50 minutes. 1976.

2 The Nonpartisan League was an agrarian organization, active in North Dakota and Minnesota from 1915 to 1922 , whose primary goal was state ownership of grain elevators and mills. 
bers of the Socialist Party, the Le Sueurs were involved in free speech fights for the IWW (Industrial Workers of the World) and during the twenties and thirties helped build the radical Minnesota FarmerLabor Association, an unusual coalition in American political history. Political activism was a family way of life for the women, too. Meridel's maternal grandmother had been an organizer for the WCTU in Oklahoma, and at the beginning of the century her mother was a speaker on the Midwest Chautauqua circuit, giving speeches on socialism and birth control. When she was 75, Marion ran for the U.S. Senate on the Progressive party ticket in Minnesota as an antiKorean War candidate. ${ }^{3}$

Meridel was brought up in a cosmopolitan, progressive environment. She attended "progressive" schools in Chicago and New York where she studied drama and dance. She lived for a while in New York with Emma Goldman in the anarchist commune. During the twenties she went to the West Coast, working for a while as an extra in the young film industry. Later her attention turned to developing a little theater group in Sacramento and Berkeley. When the Great Depression hit, she returned to the Midwest with her two young daughters to begin her prolific years as a writer and a political activist. She worked for many years for the Federal Writers' Project and with the Unemployment Councils which proliferated during the thirties.

She continued writing and publishing during the forties, fifties, and sixties and into the seventies. The McCarthy era was an especially difficult time. She was blacklisted, as were many of her contemporaries, and her only outlets for publication were the struggling radical journals. She turned to writing children's books, mostly biographical studies of legendary American figures such as Abe Lincoln, Nancy Hanks Lincoln, and Davy Crockett. Even in this genre, however, she came in for criticism. The Milwaukee Sentinel, for example, referred to her book on Abraham Lincoln as having "pink-tinged" pages.

Through all these decades, however, it would be difficult to separate Meridel the writer from Meridel the political activist. A longtime friend of Meridel's, Irene Paull, recalled:

For years the individual took second place to the collective person. There was no picket line, no struggle for civil rights, for labor's rights, for any right, that did not take precedence with her over any longing

${ }^{3}$ Meridel Le Sueur, Crusaders (New York: Blue Heron Press, Inc., 1955). This is a privately printed biography of her parents. 
she may have had to retire in peace to an ivory tower. She was in the thick of all the struggles of her times, sometimes taking cruel and unfair criticism of her work, often disappointed in men and movements, but always in possession of her Center, of her long view of history and events. ${ }^{4}$

\section{II}

Meridel's emergence as a writer in the thirties paralleled a strong literary movement unique in American history-the Literary Left. It was the Great Depression, and the political unrest of the thirties served as an influential stimulus for the development of this radical aesthetic. World War I had overburdened the American economy, and in the postwar years the weight of the debt fell on the American people. Once again the American Dream had come on hard times and once again radical politics seemed the answer. Significantly, this "new" revolution during the thirties began in the arts, and it was writers especially who responded to the call for social change. Much of the early energy and impetus for political and cultural transformation came from the John Reed clubs, the artistic branch of the Communist party. Seeking new ways to look at American culture, artists and writers turned their energies to developing a "proletarian" literature and a literary and aesthetic theory based on a working-class analysis.

The attempt to formulate this new radical aesthetic was initiated at the first American Writers' Congress in 1935. For the first time, American writers gathered to debate the role of art in American culture and to explore the relationship of art to politics. The debate among participants was often lively, and although they disagreed as to the nature of the true ideological perspective, they did come to agreement on some of the basic principles of the new aesthetic.

One of the primary characteristics of the new aesthetic was that art was to be defined in "social" rather than formalistic terms. Art was not to be for art's sake, but art necessitated by the historical and social reality. In many ways, this new aesthetic merely echoed the words of an earlier spokesman for social art-Bill Haywood, an early leader in the IWW.

[Proletarian art would be] very much kindlier than your art. There will be a social spirit in it. Not so much boasting about personality. Artists won't be so egotistical. The highest ideal of an artist will be to write a song which the workers can sing, to compose a drama which great throngs of workers can perform out of doors. When we stop

4 Irene Paull, letter to Neala Schleuning, April 1976. 
fighting each other-for wages of existence on one side, and for unnecessary luxury on the other-then perhaps we shall all become human beings and surprise ourselves with the beautiful things we can do and make on the earth. 5

In the midst of this national debate over the function of art, we find Meridel. She was a central figure at the conference, engaging in many of the discussions concerning the role of literature in a revolutionary culture. Her paper, "Proletarian Literature and the Middle West," was one of her first statements of commitment to a regional perspective, and it concludes:

We have never been burdened with the old tradition in literature from the old world. Every writer in the Middle West has had to work alone as far as connection with other writers is concerned, therefore he has been in closer contact with the American experience. An integral part of the Middle Western immediate experience is a quick adjustment, during danger, between the farmer, the industrial worker, the brain worker, the writer, the artist. They are forming a steady and quick phalange on the prairie. . . 6

Meridel is an interesting figure in American literature because she was roundly criticized during the thirties by "both sides." One recent anthologizer ${ }^{7}$ remarked that her "early promise" as a writer was destroyed when she became "political." Segments of the Left felt she was too lyrical and passionate in her style, that she didn't conform to the party line.

On the question of art and politics. I think this is where Meridel is really a person of enormous depth and complexity. For years she was active with many of us in the Marxist movement. Some did not understand or like her literary work. You young women understand and like her work far better than the Marxists did. Our imaginations were stifled in the interests of immediate propaganda. . . 8

The editors of New Masses exemplified this attitude in a footnote to "Women on the Breadlines," an article Meridel had written about the problem of women out of work during the depression.

This presentation of the plight of the unemployed woman, able as it is, and informative, is defeatist in attiude, lacking in revolutionary spirit

5 Bill Haywood, quoted in Daniel Aaron, Writers on the Left (New York: Avon, $1961)$, p. 34.

6 Meridel Le Sueur, "Proletarian Literature and the Middle West," in Henry Hart, ed., American Writers' Congress (New York: International Publishers, Inc., 1935), p. 138.

${ }^{7}$ Harvey Swados, ed., The American Writer and the Great Depression (New York: Bobbs-Merrill, 1966).

8 Irene Paull, letter to Neala Schleuning, n.d. (1976). 
and direction which characterize the usual contribution to New Masses. . . .9

Despite her critics, however, Meridel struggled to develop a new form of literature, one which can be characterized as a "dialectical realism." Art, she believed, was of necessity social, and it was the function of the writer to be passionately committed to the expression of political struggle. It was in the tension and conflict that art would be found.

You wrote in the Socialist world more like a prophet, a conduit for the suffering of your people. A cry out ... a whoop or a holler-more like the ballads of the people come to sing sorrow-a common sorrow. I also took this from the Hebraic prophets who were educators, singers, warners and opened the bundles of grief. I look upon writing as revealment, underground, subversive exposation [sic]. I mean exposing the enemy. Remarks on Kansas caves, underground journals, newspapers, leaflets, posters, mass chants. To write to expose and to rouse, awaken, wake up. Watch out. Art as action, as deep image of struggle and not bourgeois reflection. ${ }^{10}$

In this rich but neglected literary tradition, Meridel's influence is only beginning to be understood. Art, according to Meridel, has as its primary responsibility the expression of the drama of human struggle and the illumination of the magic, pain, joys, and sorrows of human relationships. She advocated a new literature which emphasized the dynamic and participatory qualities of experience and was committed to evoking the collective aspirations of humanity. To Meridel, Marxism meant that art must guide consciousness in a new direction, not merely reflect the external reality. Instead, her commitment was to expressing the affective, passional, lyrical side of human potential. She also believed in the full significance of the dialectic. Change was not linear: revolutions could and did occur across a wide range of human experience. The role of the artist was to illuminate the social, collective significance of those changes.

Meridel's insistence on grounding her art in the historical realities of the community, the people, and their struggles both politically and personally, resulted in a new aesthetic of relatedness. Literature could no longer be separate from the flux of experience. Incorporating the social base of history into literature grounded her art in the real, concrete world, the world of the Midwest.

\footnotetext{
${ }^{9}$ Footnote to "Women on the Breadlines," New Masses (January 1932), p. 7. Also quoted in Swados, op, cit.

10 Meridel Le Sueur, letter to Neala Schleuning, 1976.
} 
The body of Le Sueur's work is impressive, both for its quantity and diversity. Since 1928, when her first short story was published in the Dial, her writings have appeared in many journals: American Mercury, Scribner's, Partisan Review, New Masses, Daily Worker, Anvil, and many small, now defunct journals devoted to short fiction. She has worked in many genres: the short story, interpretive reporting, history, children's books, novellas, the novel, poetry, and personal journal writing. Her subject matter, too, has been wide ranging: from politics to intensely personal introspection.

Writing was always Meridel's primary political activity, and her style reflects a unique interweaving of politics-history-poetry. Many of Le Sueur's stories recount specific political actions between the thirties and the fifties. Even in her later poetry, she was moved to write to the women of Vietnam via a long poem integrating feminism, pacifism, and Marxism entitled "Doan Ket." "What Happens in a Strike," a story about the 1934 trucker's strike in Minneapolis; “A Hungry Intellectual," a devastating description of a man unable to make a commitment, although he was "intellectually" aware of the conflicts within the culture during the Depression; "I Was Marching!" -perhaps her best known and most powerful political statement of human solidarity and collective political action; "Murder in Minneapolis," an angry eulogy for strikers killed at the Flour City Architectural Metals company in Minneapolis; and "Minneapolis Counts Its Victims" are a few examples of her interpretive reporting of events.

In other articles she documented direct exploitation and murder. "Iron Country" was an exposé of the mining companies of the Mesabi Range who fired workers they found suffering from lung diseases; “The Derned Crick's Rose" illuminated Marx's theory of the alienation of workers from the means of production; and "The Dead in Steel" showed the courage and heroism of union organizers and their families. Other short stories and articles detailed the devastation of the land and people during the drought of the thirties in the Midwest: "Cows and Horses Are Hungry," "Tonight Is Part of the Struggle," "Salute to Spring," "The Farmers Face a Crisis," and "How Drought Relief Works." Except for her support of America's entry into World War II, Meridel has maintained a consistent pacifism in her writings, and in several short stories she examines the impact of war on victims and families: "Song for My Time," "Breathe upon These Slain," and "The Way It Seems."

Women were a special inspiration to Meridel, and we find that her 
writing encompasses the deep experiences of women long before such subjects became fashionable. One of her most highly acclaimed stories, "Annunciation," is outstanding in American literature. Carl Sandburg was moved to write:

"Annunciation" is the evocation of an original artist beautifully reverent, with a high solemnity, gravely achieved affirmations of life, an approach too infrequent among the realist and naturalist schools of writers. ... She is a witness with a genius for moving and highly implicative testimony. ${ }^{11}$

"Annunciation" encompasses in a few short pages the essence of the experience of pregnancy with its attendant sense of anticipation and wonder. In describing this experience, Le Sueur drew an analogy with the creative force itself, the emergence of new life. She begins:

Ever since I have known I was going to have a child I have kept writing things down on these little scraps of paper. There is something I want to say, something I want to make clear for myself and others. One lives all one's life in a sort of way, one is alive and that is about all that there is to say about it. Then something happens. ${ }^{12}$

The story is an internal dialogue between the woman, her unborn child, and the larger world around her. As she becomes more aware of her pregnancy, the world of poverty and want in which she lives recedes in her mind, and she builds a deep relationship with a pear tree just outside the porch of the rooming house. "I'm alone all day so I sit on this rickety porch. Straight out from the rail so that I can almost touch it is the radiating frail top of the pear tree that has opened a door for me."13

The sense of impending birth, anticipation for new life, moves the woman to powerful reflection.

How can it be explained? Suddenly many movements are going on within me, many things are happening, there is an almost unbearable sense of sprouting, of bursting encasements, of moving kernels, expanding flesh. Perhaps it is such an activity that makes a field come alive with millions of sprouting shoots of corn or wheat. Perhaps it is something like that that makes a new world. ${ }^{14}$

And she concludes:

It seems a strange thing that a tree might come to mean more to one than one's husband. It seems a shameful thing even. I am ashamed to

11 Carl Sandburg. On dust jacket of Meridel Le Sueur, Salute to Spring (New York: International Publishers, Inc., 1940). Reprinted 1977.

12 Meridel Le Sueur, "Annunciation," in Salute to Spring, p. 75.

13 Ibid., p. 78.

14 Ibid., pp. 83-84. 
think of it but it is so. I have sat here in the pale sun and the tree has spoken to me with its many tongued leaves, speaking through the afternoon of how to round a fruit. . . .15

Many of her stories deal with the lives and culture of women: "The Hell with You, Mr. Blue" concerns a woman who refuses to get an abortion; "Salvation Home" reports the practice of committing young women to mental institutions and sterilizing them; "Milk Went Up Two Cents Today" depicts the lives of women victimized by the grueling poverty of the Depression, and pregnant women unable to get milk and orange juice; "They Follow Us Girls" recounts the contemptuous attitude of relief and welfare agencies toward women clients; and "Women on the Breadlines" explores the impact of unemployment on women.

In another vein, many of her stories explore the inner, psychological world of women. It is in this group of stories that we find some of Le Sueur's best work. "Wind" takes us into the innermost thoughts of a newlywed young woman and her conflicting emotions of love and fear for the unknown man beside her. "Fudge" explores the place in a small-town culture of a spinster woman with a deep secret; and in "The Horse," a novella, Le Sueur examines the relationship of women to the violence in men. The woman who owns the horse refuses to believe that although the horse has killed his cruel trainer, he is still a killer. "Psyche," which has not been reprinted, is one of her finest stories. A redaction of the Psyche myth, it represents the depth and subtlety of Le Sueur's feminism in its early, formative stages.

Written in 1939, and rewritten and first published in 1978, The Girl is Meridel's only published novel. A very special kind of girl creates the dominant rhythm of the book-a young girl, half-formed but learning, a girl learning quickly from the life around her, a girl! growing strong in her struggle toward womanhood and a place in the culture of the people. The girl, who is never named in the book, is actually a composite of the lives of several women Meridel knew during the Depression. I hesitate to call her the "heroine" of the story, for Le Sueur's sensitive and brilliant portrayal of this young woman. cannot be so narrowly circumscribed. The girl is much more. She is: the girl in all of us, the kernel of our humanity.

The story takes us back to the thirties and the culture of poverty and oppression. Truer, deeper rhythms of that experience have seldom surfaced. The book gives us an extraordinary historical document of how people actually felt, and how they lived and sur-

15 Ibid., pp. 88-89. 
vived those dark years. While many writers during the thirties took to the road to "find" the American experience, Meridel, like most people, stayed put, and in staying with the people of the Midwest and her neighbors, she recorded their stories as they unfolded painfully through those years.

It is from the culture of women that the hungry girl seeks the way to growth and maturity. And it is from this source that The Girl gains its powerful style. The story is not so much a plot as it is a pattern, a pattern of the unfolding of an unusual yet somehow subversive culture of women. Meridel's words and rhythms move the reader into a vibrant awareness of the underlying forces of women's collective experiences. She renders in bold strokes not the "representation" of reality but the poignant and intense reality of the human-and woman's-personality.

\section{IV}

In a short essay entitled "The Regional Motive," Wendell Berry defines regionalism as follows:

The regionalism that $\mathrm{I}$ adhere to could be defined simply as local life aware of itself. It would tend to substitute for the myths and stereotypes of a region a particular knowledge of the life of the place one lives in and intends to continue to live in. It pertains to living as much as to writing, and it pertains to living before it pertains to writing. The motive of such regionalism is the awareness that local life is intricately dependent, for its quality but also for its continuance, upon local knowledge (p. 975)....

Without such knowledge and faithfulness, moreover, the culture of a country will be superficial and decorative, functional only insofar as it may be a symbol of prestige, the affectation of an elite or ingroup. And so I look upon the sort of regionalism that I am talking about not just as a recurrent literary phenomenon, but as a necessity of civilization and of survival (p. 976), 16

The Midwest and its people have been the subject matter of Meridel's writings for the past five decades. Various critics have referred to her as "the Voice of the Prairie," "the Poet of the People," and in a short poem entitled "Offer Me Refuge," Meridel indicates her own esteem for the deep roots she has sunk into midwestern culture.

$$
\begin{aligned}
& \text { My prairie people are my home } \\
& \text { Bird I return flying to their breasts. } \\
& \text { Waving out of all exiled space } \\
& \text { They offer me refuge }
\end{aligned}
$$

16 Wendell Berry, "The Regional Motive," Southern Review, V. 6, No. 4 (Autumn 1970), pp. 972-77. 


\section{To die and be resurrected in their seasonal flowering. \\ My food their breasts milked by wind \\ Into my starving city mouth. ${ }^{17}$}

Her intense commitment to the Midwest runs deep in her philosophy. It is the land itself, however, that forms the basis of her passionate love for the region.

Meridel's strong identification with the land has often been interpreted as the mark of a true "regional" writer. Regional, in this sense, suggests a spiritual significance to place: humanity in harmony with the physical environment. Her style of regionalism is not a romantic one, however. It celebrates instead the experience of oneness with nature. To the Greeks, nature was not something segregated, outside, or objectified, but the All, the Everything, the basic stuff of reality. In fusing the essential poetic imagery of American Indian philosophies with feminism and her understanding of midwestern culture, Meridel has brought us full circle. Once again we experience nature as physis.

She achieves this integration stylistically using "symbols" in a way foreign to most American writing. Her process of symbol making does not reflect the traditional Western meaning of symbols-as standing for something or as analogies for either ideas or feelings. Instead, her style reflects the Indian interpretation and use of symbols.

So symbols in Native American systems are not symbolic in the usual sense of the term. The words articulate reality-not "psychological" or imagined reality, not emotive reality captured metaphorically in an attempt to fuse thought and feeling, but that reality where thought and feeling are one, where objective and subjective are one, where speaker and listener are one, where sound and sense are one.18

Symbolizing in this sense allows simple images to evoke a participation with reality. Reading one of Meridel's poems, we experience the poem, as we do reality, from a variety of perspectives: now we are the earth speaking; now the reader listening; now the Indian people; now the mother, brother, sister. We are all these things, the poem is all these things, and the symbols and imagery reflect the poet's experience of the harmony of experience-rendered-as-process.

17 Meridel Le Sueur, "Offer Me Refuge," in Rites of Ancient Ripening (Minneapolis: Vanilla Press, 1975), p. 23.

18 Paula Gunn Allen, "The Sacred Hoop," in A. Chapman, ed., Literature of the American Indian (New York: New American Press, 1975), p. 128. 
In all her writings the images of the land as the great circle of the prairie interfuse with her imagery of politics, philosophy, and sexuality. The earth is the woman of joy and abundance, of giving, of life. The earth is the woman raped; the raped woman is the earth. The exploited land is the worker exploited, the woman abused. She returns again and again to the land, creating new images and symbols, redefining a true relationship with the earth.

The relationship of the feminine to the earth has been a dominant theme in Meridel's writings. From her earlier references to Demeter and Persephone to her later incorporation of the American Indian attitude toward the land, she has opened new insights into our understanding of nature and our place in, or with, the earth. Understanding the earth as feminine requires that we look "inside" to the inner experience and feel ourselves as we are in that place, within the body, within the curve of the prairie circle, within the midwestern village.

In a short story entitled "The Girl,"19 Meridel documents the shift in perception which allows the principal character of the story to arrive at this "new" consciousness of oneness and relationship with the land. The story is set in the West and begins with the woman driving alone through the Tehachapi Mountains. "She had read up on the history of the mountains and listed all the Indian tribes and marked the route of the Friars from the Sacramento Valley." She is a tourist, looking at the land, seeing it objectively. As she drives along, however, a change comes over her, and the land begins to affect her, intruding on her tight reality. "She drove very slowly, and something began to loosen in her, and her eyes seemed to dilate and darken as she looked into the fold upon fold of earth flesh lying clear to the horizon. ... Then hills lifted themselves out of the edge of the night. The great animal flesh jointed mountains wrought a craving in her." Finally, at the end of the story, the girl begins to understand her experience. "They didn't say anything about that in the books. She felt suddenly as if she had missed everything. She should say something to her classes. Suppose she should say-the Tehachapi Mountains have warmed and bloomed for a thousand years'. After all, why not? This was the true information."

Meridel believes that as we move into this earth-consciousness we experience the analogous sense of participation in our personal bodies and in our social bodies. Regionalism is more than a sense of physical, material place. It also necessitates a deep connection with people, and with the history of people and the land.

19 Meridel Le Sueur, "The Girl," in Salute to Spring, passim. This story is not part of her novel, The Girl. 


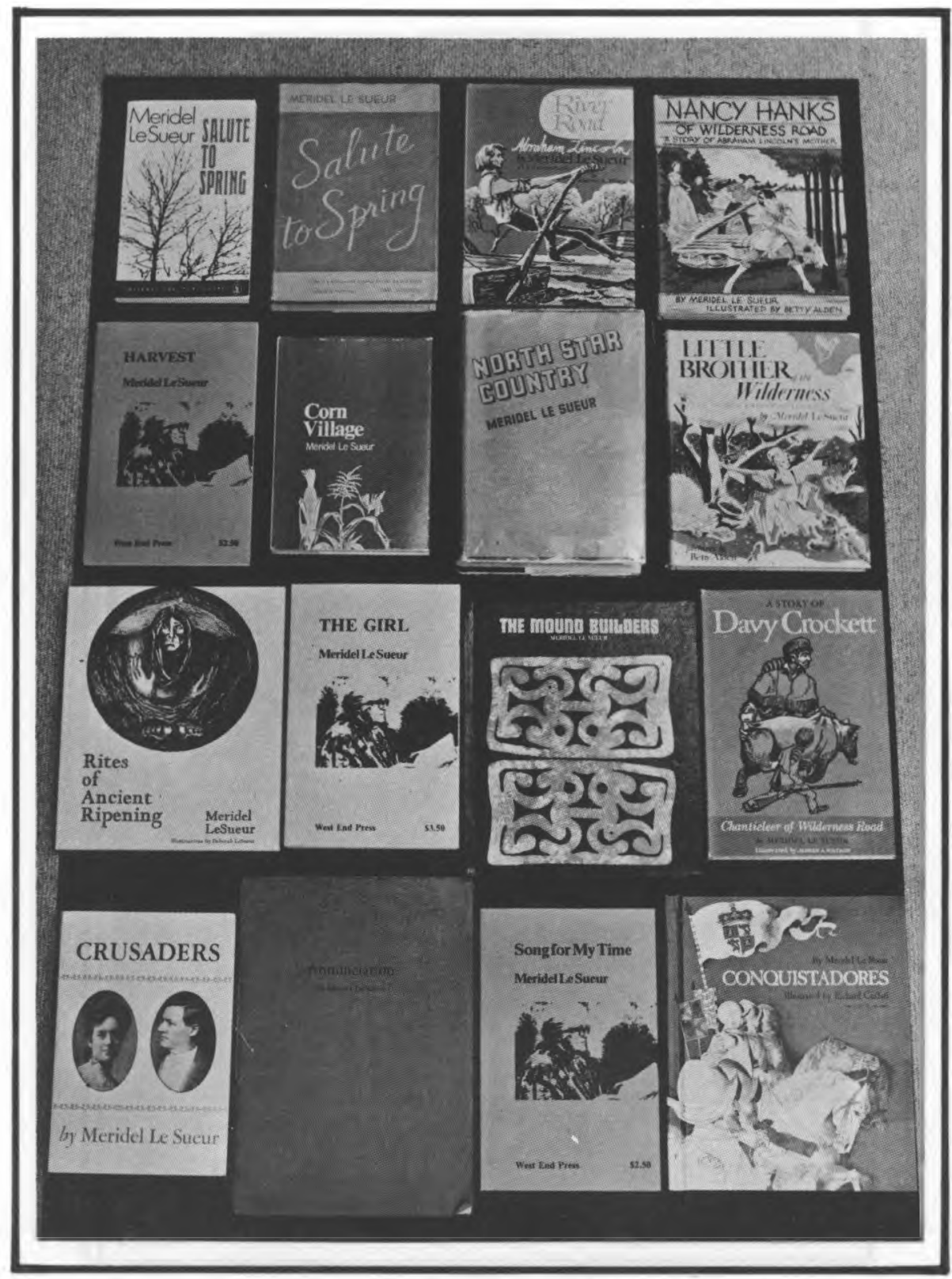

Books by Meridel Le Sueur. from the Iowa Authors Collection, The University of Iowa Libraries. 
I came out of the secret pods of the Midwest. Out of the village. It is the little place. We all emerge from the little place. We emerged from the Protestant village, from the white salt box houses. We emerged from these cellars also wounded. Yes, I felt the village. ${ }^{20}$

To achieve a sense of place and the culture of that place, the artist returns to her community, seeing her connection with a social reality and geographic space. Meridel's regionalism avoids the pitfalls of narrow provincialism and over-romanticization because she understands place as space that is experienced by the people who live and create culture there. For her, roots are the people who love the land, or change the land, or even exploit the land. Often, our relationship with the land has been a painful one, and in her story "Corn Village," Meridel recalls her own painful experiences as a child in the Midwest:

Like so many Americans, I will never recover from my sparse childhood in Kansas. The blackness, weight and terror of childhood in MidAmerica strike deep into the stem of life. Like desert flowers we learned to crouch near the earth, fearful that we would die before the rains, cunning, waiting the season of good growth. Those who survived without psychic mutilation have a life cunning, to keep the stem tight and spare, withholding the blossom, letting it sour rather than bloom and be blighted.21

Despite this somewhat bleak apprehension of the Midwest, there emerges throughout the story a deep love and passion for the land that the puritan spirit of its people cannot comprehend. She concludes the story with her own deep love for the ambiguities and inconsistencies she sees in the Midwest:

I have seen your beauty and your terror and your evil.

I have come from you mysteriously wounded. I have waked from my adolescence to find a wound inflicted on the deep heart ...

Not going to Paris or Morocco or Venice, instead staying with you, trying to be in love with you, bent upon understanding you, bringing you to life. For your life is my life and your death is mine also. ${ }^{22}$

It was in her regional history, North Star Country, written in 1945 with a grant from the Rockefeller Foundation, that Meridel brought together her special understanding of the upper Midwest. North Star Country was conceived as a "folk" history, and in many ways it anticipates our contemporary social history. Meridel did not see folk history as a mere accumulation of trivia and quaint remembrances:

20 Quoted in the film, My People Are My Home.

21 Meridel Le Sueur, "Corn Village," in Salute to Spring, p. 9.

22 Ibid., p. 25. 
A lion does not write a book. The broken trail of the people must be followed by signs of myriad folk experiences in story, myth, legend, reflecting the struggle to survive; in the spore of old newspaper, folkway marking the rituals of birth, death, harvest, planting, in the embroidery on the pillow, the democracy quilt. These signs are not to be found easily or read lightly, measured like rock, estimated as metal. Folkways are malleable. They disappear as inland rivers do and reappear to flood a continent. . . . Folklore is the hieroglyphics of all man's communication, both obvious and subterranean, as he struggles with growing society, changing tools, to create a place, a community, a nation. 23

North Star Country is rich in folksay and personal accounts, interwoven with the history of fur traders and railroad builders, farmers and politicians. Throughout the book winds the heroic story of building a democracy on the prairies. Le Sueur concludes North Star Country by bringing all these myriad forces together:

The people are a story that never ends, a river that winds and falls and gleams erect in many dawns; lost in deep gulleys, it turns to dust, rushes in the spring freshet, emerges to the sea. The people are a story that is a long incessant coming alive from the earth in better wheat, Percherons, babies, and engines, persistent and inevitable. The people always know that some of the grain will be good, some of the crop will be saved, some will return and bear the strength of the kernel, that from the bloodiest year some survive to outfox the frost. ${ }^{24}$

For Meridel Le Sueur, the prairie is that space in which she has centered her entire world view. Her vision of a global consciousness is an image born directly from the great open spaces of the Midwest. Perhaps the experience of the land does have a different feeling in the Midwest, creating a broader vision of expansiveness and spaciousness. Meridel has succeeded in translating that sense of wholeness and circularity and all-inclusiveness that bridges the religion of the prairie tribes and the early pioneer sense of awe for the great land spaces. Emerging from the little space on the prairie, expanding to the large universal space, Meridel completes her circle of life.

\section{SELECTED BIBLIOGRAPHY OF MERIDEL LE SUEUR}

Books

Annunciation, Los Angeles: Platen Press, 1935.

Crusaders. New York: Blue Heron Press, Inc., 1955.

23 Meridel Le Sueur, North Star Country (New York: Duell, Sloan \& Pearce, 1945), p. 4.

24 Ibid., p. 321. 
The Girl. New York: West End Press, 1978.

North Star Country. New York: Duell, Sloan \& Pearce, 1945.

Rites of Ancient Ripening. [Poems]. Minneapolis: Vanilla Press, Inc., 1975.

Worker Writers. Handbook, Minnesota Works Progress Administration, n.d. [1939].

Zapata. Unpublished novel.

\section{Children's Books}

Chanticleer of Wilderness Road: A Story of Davy Crockett. New York: Alfred A. Knopf, 1951.

Conquistadores. New York: F. Watts, 1973.

Little Brother of the Wilderness: The Story of Johnny Appleseed. New York: Alfred A. Knopf, 1947.

The Mound Builders. New York: F. Watts, 1974.

Nancy Hanks of Wilderness Road. New York: Alfred A. Knopf, 1949.

The River Road: A Story of Abraham Lincoln. New York: Alfred A. Knopf, 1954.

Sparrow Hawk. New York: Alfred A. Knopf, 1950.

\section{Novellas}

The Bird. New Caravan, ed. A. Kreymborg et al. New York: W. W. Norton, 1936, pp. 177-223.

The Horse. Story, 15, 1939, pp. 66-104.

O Prairie Girl Be Lonely. Cross Section, 1947, ed. Edwin Seavers. New York: Simon \& Schuster, 1947, pp. 40-71. Now included in The Girl.

Tradesman La Salle. Manuscript, 3, October 1936, pp. 33-57.

\section{Collected Short Stories}

Corn Village. Sauk City, Wisconsin: Stanton \& Lee, 1970. Includes: "Corn Village," "Persephone," "Gone Home," "Annunciation," and "Rites of Ancient Ripening."

Harvest. New York: West End Press, 1977. Includes: "What Happens in a Strike," "Women on the Breadlines," "Harvest," "Fudge," "Autumnal Village," "God Made Little Apples," "To Hell with You, Mr. Blue," and "We'll Make Your Bed."

Salute to Spring. New York: International Publishers, 1940. Reprinted 1977. Includes: "Corn Village," "No Wine in His Cart," "Fable of a Man and Pigeons," "A Hungry Intellectual," "The Girl," "Annunciation," "Biography of My Daughter," "The Dead in Steel," "Tonight Is Part of the Struggle," "Farewell My Wife and Child and All My Friends," "Salute to Spring," and "I Was Marching."

Song For My Time. New York: West End Press, 1977. Includes: "Song for My Time," "Eroded Woman," "Summer Idyl," "American Bus," "Of This Time, upon This Earth," "The Dark of the Time," and "The Return of Lazarus." 
Women on the Breadlines. New York: West End Press, 1977. Includes: "Women on the Breadlines," "Sequel to Love," "They Follow Us Girls," and "Salvation Home."

\section{Uncollected Short Stories}

“Afternoon." Dial, 84, May 1928, pp. 386-98.

"Alone in Chicago." Anvil, 5, March-April 1934, pp. 5-7.

"American Bus." Masses \& Mainstream, 8, 12, December 1955, pp. 26-36.

"The American Way." Midwest, November 1936, p. 5 and passim.

"Beer Town." Life in These United States. New York: Scribners \& Sons, 1933, pp. 156-59.

"Blues in B Flat." Madamoiselle, November 1946, p. 200 passim.

"Breathe upon These Slain." Kenyon Review, 7, Summer 1945, pp. 399-418. Also in O. Henry Memorial Award Prize Stories of 1946, ed. Herschel Brickell. Garden City, N.Y.: Doubleday \& Co., Inc., 1946.

"Christmas and the Child." Parents, December 1934, p. 16 passim.

"Cows and Horses Are Hungry." American Mercury, 33, Summer 1934, pp. 53-56. Also in Years of Protest: A Collection of American Writings of the 1930s, ed. Jack Salzman. New York: Pegasus, 1967.

“The Derned Crick's Rose." Mainstream, 9, 7, August 1956, pp. 12-21.

"Dust." The American Year: Nature Across America, ed. Henry Hill Collins, Jr. New York: G. P. Putnam's Sons, n.d., pp. 71-73.

"Evening in a Lumber Town." New Masses, 1, 3, July 1926, pp. 22-23.

"Father of the Earth." The Fountain, March 1942.

"The Glory of Robert Emmet." Masses \& Mainstream, 5, 4, April 1952, pp. 38-47.

“Holiday." Pagany, 1, Spring 1930, pp. 87-99.

"Home Sweet Home." Decade, IV, 3, First Quarter 1943, pp. 21-26.

"Home Was a Million Streets." New Masses, April 8, 1941, p. 18.

"I'm Going, I Said . . ." New Masses, January 9, 1940, pp. 17-18.

"Iron Country." Masses \& Mainstream, 2, 3, March 1949, pp. 53-60.

“The Laundress.” American Mercury, 12, September 1927, pp. 98-101.

“Milk Went Up Two Cents." Black and White, 2, 3, 1940, pp. 26-29.

"The Miracle." Pagany, III, 2, April-June 1932, pp. 1-16.

"Morning." Literary America, VI, 4, August 1934, p. 17 passim.

"My Town." New Republic, 84, September 25, 1935, pp. 175-78.

"A Night in the Woods." Masses \& Mainstream, 8, 12, December 1955, pp. 26-36.

"The Orchard." Manuscript, 1, 6, December 1934, pp. 70-75.

"Our Fathers." Intermountain Review, I, 2, February 1937, p. 1 and passim. "People in the Heat." Dubuque Dial, 2, 1934, pp. 41-42.

"Poets of Wood and Word." Common Ground, 5, 2, Winter 1945, pp. 36-40.

"Psyche." Windsor Quarterly, III, 1, Fall 1935, pp. 17-27.

"The Root." California Quarterly, 4, 1, 1954, pp. 32-37.

"Slow Train." New Masses, December 8, 1942, pp. 12, 14.

"Spring." Woman's Home Companion, April 1934, pp. 62-63. 
“Spring Came On Forever." Plainsong, 1, Spring 1967, pp. 5-17.

“Spring Story." Scribner's, 89, May 1931, pp. 553-62.

"Sunday." Decade, 11, 6, March-April 1942, pp. 1-9.

"Sure, Honey." New Anvil, June-July 1939, pp. 5-8.

"Sweet Beulah Land." Collier's, October 5, 1946.

“The Trap." Scribner's, 93, January 1933, pp. 27-32.

"The Way It Seems." Dubuque Dial, 1, 1934, pp. 22-24.

“This Is from David." Story, 17, 1940, pp. 91-101.

“Tiger! Tiger!" Harper's Bazaar, March 15, 1939, pp. 115-17.

"Wild Buffalo." Unpublished.

"Wind." Windsor Quarterly, 1, 3.

\section{Selected Early Articles}

"Benson of Minnesota." New Masses, September 6, 1938, pp. 8-10.

"The Dakotas Look Back on a Trail of Broken Treaties." Worker, March 19, 1950 , p. 4.

“The Farmers Face a Crisis." New Masses, 1936, pp. 9-10.

"The Fetish of Being Outside." New Masses, February 1935, pp. 22-23.

"How Drought Relief Works." New Masses, 20, 8, August 18, 1936, pp. 14-16.

"Midwest Writers Conference." Pacific Weekly, 5, November 16, 1936, p. 324.

“Minneapolis Counts Its Victims." New Masses, October 1, 1935, pp. 12-15.

"Proletarian Literature and the Middle West." American Writers' Congress, ed. Henry Hart. New York: International Publishers, 1935, pp. 135-38.

"Sholom Aleichem Belongs to the People." Jewish Life, VI, 5, March 1947, pp. 7-8.

"The Short Story." Manuscript News, 2, October 1935, n.p.

“The Sleepwalkers." New Republic, 75, August 2, 1933, pp. 313-14.

\section{Recent Essays}

"The Ancient People and the Newly Come." Growing Up in Minnesota, ed. Chester G. Anderson. Minneapolis: University of Minnesota Press, 1976, pp. 17-46 (autobiographical).

Continuous Woman. Film, 16mm, $30 \mathrm{~min}$. Fermme Films, Inc.

"Excerpts from 'The Origins of Corn'." New America: A Review, 2, 3, Summer-Fall 1976, pp. 20-23.

"The First Farmer's Revolt: A Tale of the American Indian's Fight for His Land." Mainstream, 15, 3, March 1962, pp. 21-26.

"Journal Excerpts." The Lamp in the Spine, Summer-Fall 1974, pp. 94-126. My People Are My Home. Film, 16mm, $50 \mathrm{~min}$. Produced by Femme Films, Inc. RR2, Box 28, Mankato, Minnesota 56001. Biographical, narrated by Le Sueur.

"People Are the Story" and "Where the Rain Falls: A Reverie-the Next Hundred Years." The People Together. Minneapolis: People's Centennial Book Committee of Minnesota, 1958, pp. 46-47.

"Struck to Ash Struck to Fire." Great River Review, 2, 1, 1979, pp. 31-46. 